\title{
Urgensi Undang-Undang Pelayanan Publik dan Pencegahan Fungsi Diskresi untuk Penyalahgunaan Kekuasaan
}

\author{
Jawahir Thontowi
}

Public Service Law is not merely important, but also useful to sthrengten a good governance and clean government in Indonesia. To make the Public Service Law is an effective legal instrument, it is required to consider several steps. The first is dealt with the important effort to make theoretical review, establish a comprehensive research, identify main problems and spesify a scope of public servant competency. The second is concerned with efforts of finding relevant arguments on public service that the Indonesian Constitusion 1945, the MPR Decree 1998, the Local Authonomy Law Number 22/1999 have indeed contributed in significant to support the Draft of Public Service Law come into existence. Finally, the Draft of PSL disfunctions to stop the abusive of power or detoumement de pouveir (corruption, collusion, and nepotism) takes place if the Indonesian government fails to control the application of the government discretion over the rule of law.

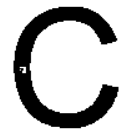

ita-cita mewujudkan Good Governance (pemerintahan yang baik) dan Clean Government telah merupakan tuntutan fundamental, baik bagi tatanan masyarakat global maupun masyarakat nasional. Prinsip-prinsip dasar tentang pemerintahan yang baik seperti demokrasi (democracy), keterbukaan (transparancy), pertanggungjawaban (accountability). supremasi hukum (rule of law) dan keadilan (justice) harus dijadikan acuan utama dalam menjalan pemerintahan. Akan tetapi, proses untuk menerapkan prinsip-prinsip fundamental tentang pemerintah yang baik terutama dalam memelihara keseimbangan hak-hak dan kewajiban antara pemerintah dengan masyarakat sebagai stake holder tidaklah mudah dilaksanakan.

Situasi tersebut bukan sekedar disebabkan karena hukum positif cenderung memperkuat peran negara atau status quo, melainkan juga disebabkan karena lemahnya partisipasi masyarakat dalam melakukan pengawasan publik. Harapan lembaga legislatif pusat dan daerah yang kandas telah berdampak atas tiadanya partisipasi masyarakat untuk melakukan pengawasan publik. Hak masyarakat untuk dapat meminta pertanggungjawaban ketika pejabat publik tidak dapat menunaikan kewajiban periu mendapatkan perlindungan dari konstitusi.

Untuk meningkatkan peran pemerintahan yang baik dan bersih diperlukan pendekatan interdisipliner. Beberapa hambatan seperti kecenderungan ethos kerja PNS yang rendah, kedisiplinan dan loyalitas untuk memperjuangkan kepentingan publik di atas kepentingan pribadi (keluarga, kelompok dan golongan), dan wabah kultural mengenai praktek korupsi, kolusi, dan nepotisme merupakan warisan 
budaya masa lalu yang masih mengakar. Praktek kenegaraan termasuk peran birokrasi pemerintah yang efisien telah diatur oleh undang-undang. Mentalitas aparat atau pegawai pemerintahan yang semula cenderung tidak mau menjadi pelayan, saat ini mutlak harus diorientasikan untuk the best practice of service harus menjadi ethos kerja mereka. Untuk itu perlu pengaturan yang terpadu atau holistik mengenai hubungan antara peran negara dengan masyarakat dalam pelayanan publik.

Persoalan yang timbul tentang pelayanan publik dari perspektif hukum bukan sekedar bagaimana fungsi dan tujuan peraturan hukum yang akan dibuat mampu membentuk cara tingkah laku aparat pemerintah yang bersih, melainkan bagaimana sebenarnya fungsi diskresi (peraturan kebijaksanaan) dapat dipertanggungjawabkan dan mampu mencegah praktek penyalahgunaan kewenangan. ${ }^{1}$

Untuk merespon persoalan di atas periu dijelaskan pertama, bagaimana wacana pelayanan publik dalam teori. Kedua, dalam situasi bagaimana suatu kebijaksanaan pemerintah (government discreation) dapat dipertanggungjawabkan dan tidak mudah di salah gunakan. Terakhir peran serta apakah yang dilakukan masyarakat dalam pengawasan terhadap diskresi dapat meminimalisir terjadinya korupsi, kolusi, dan nepotisme.

\section{Kajian Normatif Tentang Pelayanan Publik}

Pelayanan publik diartikan sebagai tindakan-tindakan pemerintah yang dilakukan untuk memenuhi kewajiban hukum bagi masyarakat dalam kaitannya dengan berbagai pemenuhan kepentingan individu dan kelompok masyarakat. Dalam sistem hukum common law pelayanan publik, antara lain mencakup tiga segi penting.

1. Poverty Law atau suatu UndangUndang Anti Kemiskinan. Negara menetapkan kelompok masyarakat yang harus hidup jangan kurang dari perolehan pendapatan minimum yang dibenarkan negara. Hal ini terutama, dipengaruhi oleh pemikiran Jeremy Bentham (1748-1832) dengan The greatest Happinest of the greates number. $^{2}$

2. Slum Clearance: upaya untuk membangun flat (rumah susun) sehingga tidak terdapat lagi masyarakat kumuh. Namun, dalam kenyataan cara ini juga tidak menguntungkan, sebab terkadang mereka bisa bernasib lebih buruk ketika penyewa di stop lantaran tidak memenuhi kewajiban terhadap pemilik rumah.

3. Perúmahan Umum (Public Housing): Undang-Undang tentang perumahan yang disediakan oleh negara terhadap pemilik dan masyarakat tempat alokasi, jorok, dan fasilitas.

Secara normatif, nilai guna the principle of utility, masiahiat sesuai dengan salah satu ajaran Islam. Kewajiban utama Nabi Muhammad dilahirkan ke muka antara lain membebaskan masyarakat dari kebodohan dan kemiskinan. Dalam beberapa ayat AlQur'an dalam Surat Al-Balad ayat 11 menegaskan yaitu bebaskan budak-budak

1 Lihat pandangan Edwin M.Schur, 1974, dalam Labeling, Morals, and Public Policy, Lee Reinwater (edited), Social Problems and Public Policy : Devance and Liberty Chicago : Aldine Publishing Company,: hlm 57

2 Lihat pandangan C.G.Weeramantry, 1975, terutama dalam memahami filsafat negara kesejahteraan. The Law in Crisis : Bridges of Understanding. London: Capemoss, hlm.197. 
dan berilah makan fakir. Begitu juga perintah memberantas kemiskinan dalam Islam tampaknya menjadi kewajiban negara sebagaimana perintah Allah, "Sesunggyhnya Allah memerintahkan kamu menegakan pemerintahan dengan adil dan kebajikan "..

Selain ketiga faktor di atas, penciptaan masyarakat sejahtera bisa dilihat dari bentuk pelayanan umum universal. Suatu pelayanan yang diberikan oleh negara atau aparat pemerintah terhadap masyarakat, yang juga ditentukan oleh derajat adanya akses untuk memperoleh kesempatan yang sama. Perumahan bagi gelandangan jelas sangat khusus, sementara pendidikan persekolahan dimana-mana universal. Kesehatan sebagai pelayanan khusus, seperti di Amerika Serikat hanya dibebaskan dari biaya jika mereka yang dalam batas umur tertentu tua, pensiunan dengan kata lain, sisa biaya bisa dikenakan kepada mereka yang mampu. Di Inggris pelayanan kesehatan memang free tanpa ada perbedaan. Ini semua bukan sekedar ada hukum, namun lebih ditentukan oleh proses pembuatan kebijakan secara umum oleh pemerintah.

Untuk terwujudnya hak-hak publik, Henry Maine sebagaimana dikutip oleh Ross Cranston menegaskan, bahwa "Nilai Hukum Baru tentang kesetaraan di depan hukum (equality before the Law) menjadi sangat penting dalam pelayanan publik.

Equality before the Law mensyaratkan adanya kemandirian (impartiality) dalam administrasi hukum dan setiap orang wajib dilayani secara setara.

Equality before the Law menuntut pentingnya paksaan atau tekanan sehingga dalam prakteknya hukum dilaksanakan secara independen dan sederajat pada tingkat pelayanannya dapat dilakukan dengan setara.
Equality before the Law perlu melihat substansi hukum dan kesederajatan yang mendapatkan pembenaran. ${ }^{3}$

Dalam kaitannya dengan hukum civil, kekurangan harta benda yang berkaitan dengan pengetahuan, keterampilan. kepercayaan diri dan lain-lain membawa pada situasi sebagian masyarakat miskin tidak berani menuntut hak-haknya. Faktor ini telah menimbulkan dampak yang merugikan bagi fungsi dan kewenangan hukum dalam pelayanan.

Dari pendekatan sosiologis, Robert S. Summer, dan Charles G. Howard, menyebutkan tujuh fungsi utama hukum, (1) meningkatkan kesehatan manusia dan kesehatan lingkungan (2) memelihara keluarga dan menjaga kehidupan pribadi (3) memelihara masyarakat damai (4) melindungi kebebasan asasi (5) menjaga kesederajatan dan kesempatan (6) mengakui dan menertibkan pemilikan pribadi (7) melaksanakan pemantauan terhadap seseorang yang berkuasa. Ketujuh faktor ini secara sosiologis cukup relevan bagi upaya memaknai norma hukum pelayanan publik. ${ }^{4}$

Sementara itu menurut pendekatan politik hukum, Alant Hunt melihat pentingnya hukum antara lain: Pertama, Hukum penting oleh karena memperlihatkan simbol atau dimensi idiologi. Hukum memobilisasi simbol-simbol idiologis. Proses legislasi dan Jegitimasi memberikan dua keuntungan langsung dan mendorong pada tekanantekanan sosial dan terkait dengan menekan terhadap timbulnya kejahatan, dapat menghambat. Hukum begitu penting oleh

3 Lihat pandangan Ross Cranston, 1985. Law in Context Legal Foundations of the Welfare State, London: Weidenfeld and Nicolson, hlm 274.

4 Ibid: hlm 325. 
karena menggambarkan dan menuntut suatu cakupan istilah yang signifikan secara idiologis. Bahasa hukum, baik secara teknis riaupun konsep populer, diwujudkan dalam suatu pernyataan tentang hak-hak, kewajiban-kewajiban, kesetaraan, keadilan.

Kedua, hukum begitu penting oleh karena secara politis bahwa ciri signifikan dari masyarakat kapitalis yang demokratis, bahwa hukum berkembang pesat dan menjadi mekanisme utama pengendalian masyarakat dan ketertiban sosial. Hal ini ditandai oleh tiga hal: hukum dipandang sebagai bentuk peraturan yang primer. Adanya perhatian terhadap kegunaan hubungan sosial bersifat juridis.

Ketiga, hukum menjadi penting juga disebabkan karena sebagian telah memainkan peranan dalam formasi kesadaran masyarakat. Pandangan kelompok kiri seperti Lenin, menegaskan Law is but an expression of the needs and will of a dominant class ${ }^{5}$.

Berdasarkan pemaparan di atas, maka norma hukum pelayanan publik menjadi sangat penting bukan saja dalam kaitannya dengan adanya kepastian hukum bagi masyarakat, untuk memperoleh pelayanan seperti ; perumahan, kesehatan, pendidikan, dan aspek lainnya melainkan juga fungsi norma hukum pelayanan publik yang dapat dipergunakan untuk menyelesaikan konflik antara pejabat pemerintah dengan masyarakat.

\section{Diskresi dalam Pelayanan Publik}

Bilamana aspek juridis berbicara tentang pelayanan publik lebih menekankan pada perlunya pejabat atau pegawai negeri patuh pada hukum, maka diskresi merupakan kewenangan yang ada di luar ketentuan hukum. Bagi pemerintah, ketentuan peraturan hukum terkait dengan aspek pelayanan tidak selalu tuntas, kehadiran jumlah peraturan yang begitu banyak dan detil tentu akan berakibat fungsi hukum akan menjadi cepat ketinggalan.

Meskipun demikian, pentingnya diskresi bagi pemerintah yaitu karena ruang lingkup pelayanan selain begitu banyak jumlahnya, juga sangat tehnis sekali dalam pencapaiannya. Karena itu, dalam pencapaiannya diskresi juga dibuat terdiri dari keputusan-keputusan. Mengapa diskresi dalam konteks peningkatan pelayanan publik perlu dikedepankan, karena dapat menjadi instrumen pelengkap bagi keberadaan undang-undang. Untuk memahami kebijakan dan diskresi bagi peningkatan pelayanan publik, maka penting untuk dijelaskan secara singkat apa maksud dan fungsi diskresi.

Secara sederhana, diskresi atau kebijakan tergolong perbuatan administrasi pejabat pemerintah eksekutif yang dibuat melalui keputusan atas suatu kebutuhan tertentu karena tiadanya peraturan hukum yang dikeluarkan oleh lembaga legislatif. Dalam konteks hukum perdata, misalnya kata-kata discretion statement yaitu suatu pernyataan yang dikeluarkan oleh seseorang penggugat yang memohon cerai, dengan harapan bahwa pengadilan dapat menerapkan kebijakan oleh karena tiadanya aturan hukum. Sedangkan contoh lain, diskresi juga dapat diterapkan oleh petugas pajak, ketika para pembayar pajak memberikan kepercayaannya untuk

5 Lihat pandangan Alant Hunt, 1981 dalam Karyanya The Politics of Law and Justice in Politics and Power: Law, Politics, and Justice. London: Rontledge \& Kegan Paul, hlm: 7. 
menerapkan kebijakan absolut terhadap pendapatan dan modal dari pemiliknya. ${ }^{5}$

Menurut D.J. Galligan diskresi merupakan suatu bentuk putusan penting dalam sistem hukum moderen dimana para petugas-petugas apakah mereka pegawai pengadilan atau administrasi membuat putusan-putusan ketika tiadanya peraturan hukum yang pasti dan jelas. Memang dilakalangan ahli-ahli hukum, diskresi dalam praktik peradilan menjadi persoalan yang sangat tajam deperdebatkan. Namun, mereka mentolelir terhadap diskresi bagi pejabat pusat atau daerah dalam kaitannya dengan pelaksanaan pemerintahan. Diskresi dapat dijadikan suatu kewenangan yang dapat dipergunakan oleh pejabat dalam kaitannya pelaksanaan tugas pelayanan, yang ketentuan prosedur tehnisnya tidak tersedia aturan hukumnya dalam undangundang.

Menurut Galligan terdapat tiga syarat yang harus dipenuhi dalam pembuatan diskresi. Ketiga syarat tersebut antara lain rasionalitas (rationality), maksud dan tujuan (purposiveness), dan moralitas (morality) ${ }^{7}$ Suatu diskresi dipandang rasional bilamana keputusan tersebut dibuat benar-benar dapat dipahami oleh akal sehat masyarakat. Meskipun dalam kenyataan putusan dibuat rasional atau dipandang oleh yang lain tidak atau kurang rasional, maka sebenarnya rasionalitas itu sangat tergantung pada obyek dan cara-cara yang tersedia dalam memperoleh tujuan.

Sedangkan maksud dan tujuan dari adanya diskresi harus mewujudkan adanya prinsip-prinsip dasar moralitas yang sangat penting, terkait dengan pemahaman hak-hak atas kepentingan-kepentingan individu yang perlu diutamakan, Dalam mencapai tujuan, penyampaian gagasan secara terbuka, substansi hukum antara prosedur serta perlakuan non-diskriminasi sangat perlu ditekankan.

Aspek moralitas dalam diskresi yaitu dibuat oleh pejabat pemerintahan yang selalu mengaitkan dengan dasar-dasar moralitas politik, yang mewujud pada lahirnya suatu prinsip-prinsip khusus dan prioritas yang menyediakan petunjuk bagi pejabat yang membuat diskresi, termasuk menyediakan kerangka dasar bagi ketelitian dan pengujian dalam proses pembuatan keputusan, baik itu oleh pembuat undangundang, petugas pengadilan atau pejabat lainnya. ${ }^{\mathrm{B}}$

Dalam literatur hukum Indonesia, diskresi dapat disamakan dengan peraturan kebijaksanaan (beleidsregel, policy rule), yaitu badan atau pejabat tata usaha negara yang bersangkutan merumuskan kebijaksanaannya itu dalam berbagai bentuk "jurisdische rege/s", seperti halnya peraturan, pedoman, pengumuman, surat edaran dan mengumumkan kebijaksanaan itu. Dengan kata lain, diskresi itu suatu putusan yang dikeluarkan oleh suatu badan administrasi negara yang tidak memiliki kewenangan membuat undang-undang. Diskresi tidak memberikan ikatan hukum secara langsung, namun tetap relevan terhadap hukum.

Menurut Philiphus Hadjon (et al), pembangunan dewasa ini agaknya telah pula dilandasi dengan perbagai perangkat peraturan kebijaksanaan, kesemuanya mencerminkan betapa semakin bertambahnya kadar penggunaan freies er mesen dari

${ }^{8}$ Lihat John B. Saunders, 1977, Mozley \& Whiteley's Law Dictionary.(Ninth Edition). London: Butterworths. hlm 106.

7 Lihat D.J.Galligan, 1990, Discretionary Powers : A Legal Study of Officials Discretion. Oxford : Clarendon Press, hlm 5.

${ }^{\circ}$ Lihat Galligan ; lbid hlm 5. 
badan atau pejabat tata usaha negara di dalam hal upaya pemberian pelayanan publik bagi masyarakat. ${ }^{9}$

Terhadap diskresi ini, Weeramantry mengingatkan peran pembuatan keputusan diskresi dilakukan dengan hati-hati oleh karena luasnya wilayah hukum administrasi berakibat fungsinya tidak dapat efektif. Berbagai hal diluar ketentuan hukum yang ada tidak mudah terlibat dalam kebijakan yang adil (Discretionary Justice). Dimana pejabat memiliki kebijakan kebebasan diskresi, yang sebagian besar tidak dapat dikontrol. Karena itu, problem diskresi yang dipandang oleh hukum tidak cukup memadai, Dalam beberapa aspek penting diskresi dapat melahirkan pertentangan yang serius terhadap peraturan hukum. ${ }^{10}$

Konsekuensi peraturan kebijaksanaan atau diskresi yang tidak terawasi dapat membawa dampak negatif ketika tidak ada pengawasan efektif. Penyalahgunaan wewenang atau abuse of power, suatu perbuatan yang dilakukan oleh pejabat atau pegawai negeri yang dapat menimbulkan kerugian bagi masyarakat yang dilayani. Perbuatan korupsi, kolusi, dan nepotisme tergolong pada perbuatan pejabat yang bertentangan dengan asas keadilan dalam tegaknya pemerintah yang baik.

Menurut W.F. Wertheim, dalam kehidupan sehari-hari bila seorang pegawai negeri menyalahgunakan wewenang yang ada padanya untuk memperoleh penghasilan tambahan bagi dirinya dari masyarakat tergolong perbuatan curang. " Dengan kata lain, seorang pejabat dikatakan melakukan tindak pidana korupsi bilamana ia menerima hadiah dari seseorang yang bertujuan mempengaruhinya agar ia mengambil keputusan yang menguntungkan kepentingan sipemberi hadiah. Perbuatan korupsi itu juga mencakup menawarkan jasa atau hadiah, meminta hadiah sebagai balas jasa karena suatu tugas yang merupakan kewajiban sebagai pelayanan. Di Asia Tenggara penyimpangan kekuasaan melalui praktek korupsi tersebut sungguh tidak mudah mencari jalan keluarnya.

Berkembangnya penyalahgunaan kekuasaan dalam bentuknya korupsi tidak berarti bahwa tidak ada peraturan hukum. Sejak zaman Belanda peran KUHP seperti yang tertera dalam pasal 209 ayat (1) cukup jelas. Intinya memberikan suatu hadiah mempunyai pengertian yang lain dari sekedar memberikan sesuatu karena kemurahan hati, melainkan sebagai suapan. ${ }^{12}$ Studi yang dilakukan oleh Jose Veloso Abueva tentang hubungan antara nepotisme dan pembagian ruang dengan peran pejabat publik dapat dipandang positip.

Nepotisme dan sistem bagi - rezeki juga menyumbang pembangunan politik dengan cara berikut. Dengan bertambahnya jumlah warganegara yang mendapat pekerjaan, layanan, dan kesempatan menikmati sumber-sumber pemerintah, keyakinan dan sikap mereka terhadap negara berubah. Negara tidak lagi merupakan sesuatu yang jauh dari kehidupan sehari-hari yang tak perlu

${ }^{9}$ Lihat Philiphus Hadjon (et al), 1993 Pengantar Hukum Administrasi Indonesia (Introduction to Indonesian Administrative Law), Yogyakarta Gajah Mada University Press, hIm. 151-152.

${ }^{10}$ Weeramantry, Op-cit 217.

"Lihat W.F.Werthein,1977, Segi-segi Sosiologis Korupsi di Asia Tenggara. Muchtar Lubis dan James Scott. Bunga Rampai Karangan-Karangan Etika Pegawai Negeri. Jakarta Bhatara Karya Aksara, hlm.13.

${ }^{12}$ Lihat P.A.F. Lamintang,1991, DelikDelik Khusus Kejahatan Jabatan Tindak Pidana Korupsi; Bandung. CV. Pionir Jaya, hlm 259. 
dihiraukan, atau sesuatu yang menindas yang harus dijauhi. Berangsur-angsurnegara jadi sesuatu yang nyata dan berguna yang pantas dipercayai dan diberi dukungan. Ikut serta dalam kegiatan-kegiatan negara mencetuskan rasa ikut memiliki, merupakan langkah pertama ke pengabdian. Birokrasi sekarang jadi tangga yang penting untuk pindah kedudukan sosial dan karena itu juga jadi kekuatan penyatu dan penertib, dimana biasanya masyarakat berkelas-kelas, kesukuan, kesetiaan sempit, dan sikap curiga memecah belah rakyat dan merintangi perorangan mencapai kemajuan pribadi dan merintangi tersebarnya kesadaran nasional. ${ }^{13}$

Apakah praktek KKN yang terjadi di negara-negara ketiga itu timbul disebabkan oleh tiadanya peraturan hukum atau karena adanya aspek-aspek di luar hukum. Sebagaimana dikemukakan oleh Jose di atas, maka disamping nepotisme, kolusi, dan korupsi memiliki segi positif, dampak negatif bagi masyarakat tidak dapat dihindari. Sebagaimana berkembang di negara-negara ketiga seperti Indonesia.

\section{Relevansi UU Pelayanan Publik}

Hadirnya keinginan-keinginan untuk membuat UU Pelayanan Publik memang penting dan tentu berguna. Secara makro, UU Pelayanan Publik dapat ditempatkan dalam hukum administrasi negara. Akan tetapi, kontroversial diantara pakar hukum dan sosial memang masih cukup dilematis.

Pendapat pertama, menegaskan bahiwa UU Pelayanan Publik menjadi tidak perlu karena upaya-upaya pemerintah melalui lembaga legislasi, yaitu pembuatan UU tidak selalu memperlancar upaya mencari jalan keluar bagi suatu krisis. Meningkatnya keinginan membuat UU dalam berbagai aspek malah dapat menimbulkan duplikasi. Romli Kartasasmita dengan tegas mengkritisi pembuatan UU Pelayanan Publik dengan perlunya mengkaji secara komprehensif. Dewasa ini di Indonesia, bukan lagi mencari jawaban atas pertanyaan bagaimana membuat hukum (how to make the law), melainkan justru bagaimana membuat hukum itu efektif (how to make effective $)^{14}$. Selain harus dipertimbangkan landasan filosofis, sosiologis, dan juridis, juga tekhnik legal drafting perlu menjadi perhatian.

Bagi yang tidak setuju, UU Pelayanan Publik tidak perlu karena undang-undang organik yang sifatnya sektorai telah cukup tersedia. Misalnya, UU No. 5 tahun 1960, tentang Peraturan Dasar Pokok-Pokok Agraria, UU nomor 1 tahun 1967, tentang Penanaman Modal Asing, UU nomor 11 tahun 1967 tentang Ketentuan-Ketentuan Pokok Pertambangan, UU nomor 6 tahun 1968 tentang Penanaman Modal Dalam Negeri, UU nomor 9 tahun 1992 tentang Keimigrasian, UU nomor 14 tahun 1992 tentang Lalu Lintas dan Angkutan Jalan, UU nomor 23 tahun 1992 tentang Kesehatan, dan UU nomor 1 tahun 1995 tentang Perseroan Terbatas. UU yang disebut terakhir, pemerintah secara eksplisit menyebutkan mengenai peran pemerintah untuk melakukan pelayanan publik dalam bidang kesehatan. Ketika berbicara tentang

13 Lihat Jose Veloso Abueve, 1977, Sumbangan Nepotisme, Sistem Bagi-Rejeki dan Korupsi Pada Pembangunan Politik. Muchtar Lubis dan James Scott. Bunga Rampai Karangan-Karangan Etika Pegawai Negeri. Jakarta. Bhatara Karya Aksara, hlm. 107.

${ }^{14}$ Pandangan ini dikemukakan dalam acara Panel Diskusi, diselenggarakan oleh Departemen Aparatur Negara, tanggal 16 April 2003, di Jakarta. 
UU maka objek yang diatur mestinya harus menunjuk pada sesuatu tertentu. Kelemahan yang dikemukakan oleh Romli terhadap Rancangan UU Pelayanan Publik tumbuhnya berbagai kasus dalam pelaksanaan fungsi pelayanan publik yang melibatkan pejabat birokrasi, sering ditempuh secara konvensional yaitu dengan melakukan kajian dari UU Kepegawaian.

Selain itu, menurut Romli, yang sering terlupakan karena kasus-kasus itu timbul akibat hubungan pengaruh antara UU organik dengan non-organik. Bahkan kemungkinan kelemahan (Joopholes) dalam UU organik merupakan penyebab utama dan digunakan oleh stakeholder yang beritikad tidak baik bersama-sama birokrasi untuk memperoleh keuntungan pribadinya. ${ }^{15}$

Ketidaksetujuan atas RUU Pelayanan Publik juga terkait dengan istilahnya yang terlalu umum. UU ini nantinya mampu menjadi suatu instrumen hukum yang dapat menciptakan keseimbangan hubungan antara hak-hak dan kewajiban negara dengan hak-kewajiban warga negara. Dengan banyak UU organik dan nonorganik, pemerintah telah gagal mempertanggungjawabkan kewajibankewajibannya, hak masyarakat untuk melakukan komplain dan aksi, dapat dilindungi oleh undang-undang. Karena itu, jika landasan filosofis perlunya undangundang pelayanan publik tidak menjembatani terealisasinya sila ke lima terciptanya masyarakat yang adil dan makmur dalam aspek ekonomi, politik, pendidikan dan juga kesehatan, maka masyarakat akan kehilangan kepercayaan terhadap pemerintah.

Terakhir, luasnya wilayah garapan dari persoalan pelayanan publik juga menjadi penyebab keraguan akan berhasilnya UU Pelayanan Publik. Misalnya terdapat tiga persoalan pelayanan publik yang terkait dengan hubungan hukum antara warga negara dengan aparat pemerintah. Pertama, hak pelayanan publik adalah hak yang mestinya diperoleh warga negara atau masyarakat yang timbul dari konsekuensi penunaian kewajiban masyarakat terhadap pemerintah, sehingga masyarakat dapat menuntut pelayanan berkualitas. Akses informasi, mendapat perlindungan nondiskriminatif, kesamaan peluang, memperoleh kompensasi dan ganti rugi dsb.

Kedua, kewajiban pelayanan publik adalah merupakan wujud dari negara atau aparat pemerintah untuk menunaikan kewajiban yang harus atau tidak diharuskan untuk melakukan sesuatu sesuai.peraturan hukum lainnya. Wujud dari kewajiban tersebut antara lain terkait dengan unsur ; (a) Pemenuhan persyaratan dan prosedur yang benar dalam pelayanan. (b) terlibat dalam pemeliharaan sarana pra-sarana pelayanan, dan (c) mematuhi peraturan UU dan sejenisnya terkait dengan tugas dan kewenangannya.

Ketigà, hak dan kewajiban penyelenggara publik yaitu hak-hak yang ditetapkan UU bagi institusi pelaksana untuk mempëroleh tugas dan kewenangan, penentuan prasarat dan prosedur teknis (perizinan), memperoleh dan menentukan sumber biaya, dan hak untuk melakukan pembelaan. Konsekuensinya, institusi publik berkewajiban untuk menyediakan sarana dan pra-sarana sehingga tuntutan masyarakat dalam kaitannya dengan

${ }^{15}$ Lihat Romli Atmasasmita. "Komentar Terhadap RUU Pelayanan Publik" ; Seminar Pengembangan Konsepsi Hukum Pelayanan Publik. Diselenggarakan oleh Deputi Bidang Pelayanan Publik Menpan. Jakarta 16 April 2003, him. 3 
pemenuhan kebutuhan hak-hak fundamental (sosial, ekonomi) dapat terpenuhi secara lancar. ${ }^{16}$ Karena itu, dalam realisasi penyelenggara pelayanan publik harus dilengkapi dengan asas-asas, norma kesusilaan, kepatuhan dan norma hukum, efisiensi, akuntabilitas, murah, cepat, dan transparan agar fungsi mereka sesuai tuntutan yang digariskan.

Bagi mereka yang setuju, hasrat membuat UU Pelayanan Publik itu juga cukup alasan. Pertama, sejak diterapkan UUD 1945 pasca amandemen, maka hakhak pelayanan publik terbukti semakin kompleks. Tim Peneliti Universitas Indonesia, menyimpulkan sekitar empat puluh tiga butir yang merupakan hak publik ${ }^{17}$ dan sebenarnya dapat dibedakan kepada tiga kelompok.

Meskipun konstitusi RI belum dapat sepenuhnya mengaktualisasikan fungsi hukum sebagaimana dirumuskan dalam pendekatan sosiologis dan politis, pokok pikiran Pembukaan Undang-Undang Dasar 1945 menujukan dengan tegas dan pasti. Perkembangan lebih positif juga dibuktikan melalui proses amandemen terhadap UUD 1945, yang lebih membuka peluang bagaimana pelayanan publik dapat memperoleh kepastian dari konstitusi.

Negara --- melindungi segenap bangsa Indonesia dan seluruh tumpah darah Indonesia dan untuk memajukan kesejahteraan umum, mencerdaskan kehidupan bangsa, dan - - .

Acuan dasar tersebut, penjabaran lebih lanjut diatur dalam pasal 31 (5 ayat) dan pasal 32. Jika dipelajari maka norma hukum dalam pasal 31 mengandung keseimbangan hak dan kewajiban antara pemerintah dengan rakyat. Pertama, selain hak juga kewajiban masyarakat untuk memperoleh pendidikan. Kedua, pemerintah wajib menyediakan biaya, termasuk mengupayakan fasilitas. Sekurang-kurangnya $20 \%$ anggaran tersebut disediakan untuk menunjang pendidikan, sehingga terselenggara pendidikan nasional serta memajukan ilmu pengetahuan dan teknologi serta nilainilai agama.

Kemudian dalam Sidang Tahunan Majelis Permusyawaratan Rakyat (ST MPR) 2002 terjadi terobosan yang cukup penting dalam disetujuinya amandemen UUD 1945. Setelah melalui proses yang cukup alot, amandemen ini menghasil perubahan terutama dalam pencantuman lebih lengkap bagi tanggung jawab negara dalam menjamin pemenuhan hak-hak dasar masyarakat. Komitmen ini memang bukan hal baru, karena jaminan hak-hak publik itu sudah ada ketika UUD 1945 pertama kali dibentuk. Yang selalu menjadi masalah adalah pelaksanaan hak-hak itu, karena kuatnya intervensi setiap penyelenggara negara atas berbagai klausul dalam konstitusi.

Sedangkan upaya-upaya kearah terciptanya kesejahteraan hak-hak diatur perekonomian nasional dalam pasal 33 terdiri (5 ayat) dan pasal 34 (4 ayat). Sedangkan isyarat dalam pasal 34 antara lain negara selain wajib memelihara fakir miskin dan anak-anak terlantar, juga berkewajiban untuk mengembangkan sistem jaminan sosial, sebagai mana pula berkewajiban untuk penyediaan fasilitas pelayanan kesehatan dan fasilitas umum yang layak

Dalam beberapa pasal sangat jelas

16 Disajikan dari bahan Seminar Penyusunan Rancangan UU tentang Pelayanan Publik. Kementrian PAN, Deputi Bidang Pelayanan Publik, 2000, hilm 2.

${ }^{17}$ Op.cit. Tim Peneliti UI, hlm 112-113. 
dipaparkan jaminan negara terhadap hakhak masyarakat. Misalnya hak berkedudukan sama di dalam hukum dan pemerintahan, hak untuk mendapatkan pekerjaan dan kehidupan yang layak, termasuk jaminan negara terhadap fakir miskin dan anak-anak terlantar, hak untuk mendapatkan pendidikan, dan hak rakyat untuk mendapatkan hasil yang sebesar-besarnya dari hasil kekayaan sumber daya alam Indonesia. Hak-hak itu dikategorikan sebagai hak-hak publik. Tugas pelayanan publik adalah bagaimana aparatur pemerintahan memberikan pelayanan maksimal bagi terselenggaranya hak-hak publik itu dengan baik.

Kelompok pertama, kepentingan publik dari segi hukum mencakup kedudukan yang sama dalam hukum (27 ayat 1$)$, perlindungan, jaminan keamanan, dan proses hukum yang wajar (28 ayat 1 ), pengakuan hak pribadi dalam hukum (28! ayat 1), hak untuk tidak dituntut atas dasar hukum yang berlaku surut ( $28 \mathrm{I}$ ayat 1 ). Termasuk hak untuk tidak diperlakukan diskriminatif dan disiksa ( 28 I ayat 1 ).

Kelompok kedua, pelayanan publik terkait dengan aspek ekonomi. Hal tersebut mencakuphak memilih pekerjaan ( $28 \mathrm{~B}$ ayat 2), hidup sejahtera lahir bathin, bertempat tinggal, menghirup udara yang baik dan sehat (28 $\mathrm{H}$ ayat 1 ), Jaminan Sosial $(28 \mathrm{H}$ ayat 3 ). memiliki hak milik pribadi dan hak pribadi yang tidak boleh diambil sewenang-wenang (28 $\mathrm{H}$ ayat 4 ).

Kelompok ketiga, pelayanan publik terkait dengan hak-hak pendidikan dan kesehatan mencakup hak mendapatkan pendidikan, manfaat ilmu teknologi dan budaya (28 $O$ ayat 1), keagamaan, keyakinan, ideologi (28 B ayat 2 ), (pasal 31 ayat 1). Termasuk hak untuk mencari informasi dan menggunakan saluran media yang tersedia (28 F).

Kelompok keempat, pelayanan publik terkait dengan hak-hak sipil yang antara lain mencakup hak untuk hidup (28 I ayat 1 ), hak hidup dan mempertahankannya (28 A), hak membentuk keluarga dan melanjutkannya melalui perkawinan yang $\operatorname{sah}(28 \mathrm{~B}$ ayat $1 \& 2$ ).

Kelompok kelima, pelayanan publik terkait dengan hak-hak poitik dan sosial. Hak tersebut mencakup kebebasan berpendapat, berserikat, berkumpul (pasal $28 \mathrm{E})$, mempertahankan martabat (28 A), mendapatkan suaka politik dari luar negeri (28G ayat 2).

Argumen ketiga, visi dari perlunya UU Pelayanan Publik juga terkait dengan upaya menciptakan keseimbangan antara hubungan kekuasaan pusat dan daerah. Peningkatan pelayanan publik yang memuaskan juga telah didukung oleh UU No.22/1999 dan UU No.25/1999 PAD. Bahkan bagi Aceh, lahirnya UU No.18 Tahun 2000, mengidentifikasikan bukan saja pemerintah memiliki otonomi dalam pemberdayaan ekonomi masyarakat, melainkan juga kepuasan budaya dan keagamaan mereka.

Berdasarkan kelima kelompok hak pelayanan publik tersebut, menjadi perlu untuk mengimplementasikan, bukan sekedar membuat UU yang lebih operasional, melainkan justru harus dapat berlaku efektif. Biasanya nilai efektivitas mata aturan hukum terkait dengan aspek keadilan.

Salah satu ukuran adanya keadilan harus dapat diukur oleh adanya kepentingan sebagai tuntutan atau hasrat dari umat manusia, kepentingan individu (individual interest), kepentingan publik (public interest), dan kepentingan sosial (social interest); kepentingan kemanan masyarakat, 
kehidupan individu, perlindungan terhadap moral, pelestarian kehidupan sumber pisik dan sosial, kepentingan ekonomi, politik, dan budaya ${ }^{18}$. Ukuran keadilan juga harus sama seimbang diterapkan, terutama ketika pejabat negara harus diberi sanksi hukum ketika mereka lalai atau gagal dalam melaksanakan tugasnya. ${ }^{19}$.

Meskipun ruang lingkup pelayanan publik belum terumuskan secara komprehenship (karena masih dalam pencarian), hukum pelayanan publik yang akuntabel mengharuskan beberapa parameter hukum kritis (legal critics) di bawah ini.

\section{Diskresi dan Penyalahgunaan Kewenangan}

Kurangnya kualitas pelayanan publik yang dilakukan pemerintah terhadap masyarakat atau kliennya bukan sekedar disebabkan tiadanya peraturan hukum, melainkan disebabkan oleh adanya pembuatan diskresi yang disalahgunakan untuk kepentingan pribadi.

Menurut Philipus Hadjon, untuk menentukan ada tidaknya suatu pelanggaran yang dilakukan oleh pemerintah perlu dirumuskan dua cara dalam hukum administrasi negara. Pertama, pentingnya norma hukum mengenai legalitas tindakan pemerintah. Kedua, menentukan seberapa jauh norma kepatuhan perilaku aparat dapat memenuhi kualitas pelayanan publik. Dari kedua hal tersebut, norma hukum yang dilanggar pemerintah dapat berupa pelanggaran atas asas keselamatan, norma kewenangan, peraturan hubungan kerja dan penyalahgunaan kewenangan (deteurment de pouvoir). ${ }^{20}$

Dari fakta itu menunjukan bahwa mustahil di satu pihak penyalahgunaan kewenangan dapat diberantas, tanpa dibarengi dengan penerapan undang-undang terkait dengan pelanggaran jabatan diterapkan secara efektif. Delik-delik khusus dalam KUHP tentang kejahatan jabatan dan korupsi, termasuk UU Korupsi dan Monopoli dapat menjerat pejabat negara dan PNS yang tidak memenuhi kewajiban secara benar. Penerapan sanksi hukum dari bentuk teguran sampai dengan hukuman penjara bagi PNS memang tidak akan memadai. Sebab, selain faktor fungsi hukum yang tidak efektif, jauh lebih dominan PNS umumnya memiliki status ekonomi lemah, dan apalagi masyarakat parokialisme dengan berbagaj kelemahan lainnya.

Terdapat beberapa kasus yang memperlihatkan hubungan antara tindakan pemerintah berupa diskresi dengan timbulnya penyalahgunaan wewenang.

Gubernur DKI mengijinkan penggunaan sebagian kawasan Taman Puring untuk berjualan, padahal taman ini diperuntukan jalur hijau. Gubernur DKI juga mengijinkan penggunaan sebagian lahan untuk mendirikan pompa bensin, padahal tanah ini sebagai jalur hijau.

Dalam kasus diatas, tindakan Gubernur memberi izin tersebut tergolong penyalahgunaan kewenangan (deteournament de pouvouir), yang tidak tergolong diskresi, melainkan memang bertentangan dengan hukum tata kota dan lingkungan. Namun,

18 Steven Vago,1981, Law and Society, New Jersey Prantice Inc. hlm 17. Ibid: 44 .

19 Lihat Laporan Akhir Naskah Akademik RUU Tentang Pelayanan Publik, Jakarta: Lembaga Penelitian Ul, halaman 34.

${ }^{20}$ Lihat Philiphus M.Hadjon dan Tatiek Sri Djatmiarti. "Analisis Rancangan Norma Hukum Menyangkut Pelayanan Publik." Disampaikan dalam Seminar Konsepsi Pelayanan Publik dalam Rangka Penyusunan RUU Tentang Pelayanan Publik. Deputi Bidang Pelayanan Publik Kementrian Jakarta 16 April 2003. 
pertentangan tersebut bukan sebagai akibat ketidakpahaman terhadap hukum, tapi justru sebagai upaya mencari jalan keluar yang lebih bernilai guna. Umumnya ditemukan di lapangan bahwa penggunaan tempat terlarang kemudian mendapatkan legalisasi sebenarnya bukan tanpa maksud. Daripada tempat tersebut rusak atau kumuh. pedagang-pedagang kaki lima diperbolehkan melakukan aktifitas dengan syarat misalnya menjaga dan ketertiban dan memelihara kebersihan. Namun, persyaratan itu dilanggar menjadi tidak efektif oleh karena selain lemahnya pengawasan, juga pedagang kaki lima tidak pernah lapor resmi dan juga pajak tidak resmi berupa pengompasan dari preman-preman ibu kota. Dalam kasus lain, tetapi memiliki substansi yang sama yaitu amburadulnya sistem transportasi di Jakarta. Sebenarnya aksi oper penumpang itu memang sesederhana alasan yang dikelompokkan oleh sejumlah sopir. Kami harus mendapatkan uang setoran dengan berebut dengan bus lain. Lebih baik kami berputar sehingga mendapat penumpang sebanyak-banyaknya. ${ }^{21}$

Memperhatikan kasus diatas, maka dilema penyalahgunaan kewenangan di Pemda DKI, bukan sekedar ada atau tidaknya aturan hukum. Justru disebabkan karena desakan urbanisasi akibat ledakan penduduk dan situasi masyarakat yang terhimpit secara ekonomi. Kompleksitas persoalan disekitar kebijakan perijinan yang dipandang sebagai penyalahgunaan persoalan moralitas, apakah layak dalam situasi yang dilematis tersebut tindakan yang di satu pejabat DKI dituntut di pengadilan sebagai suatu pelanggaran jabatan. Padahal di satu pihak (pedagang kaki lima, dan kaum tunawisma) telah memberi manfaat dan nilai guna, dan di pihak lain bertentangan dengan ketentuan hukum lingkungan. Sama halnya dengan isu pemerintah DKI Jakarta nekat mereklamasi pantai utara. Keberatan memberi lingkungan tak dianggap. Sebab, pandangan Menteri itu bertentangan dengan Peraturan Pemerintah No.27 1999, yang menegaskan bahwa kewenangan nilai modal suatu proyek Pantura dialihkan menjadi wewenang pemerintah propinsi. ${ }^{22}$

Dalam kasus berikut, Petugas Kelurahan yang mengenal atau memperoleh keuntungan dari pembuatan KTP. Begitu juga petugas Kelurahan Cabangbungan, Bekasi menjual belikan biaya surat nikah.

Dilihat dari segi pertanggungjawaban hukum, jelaslah pak lurah tersebut dikualifikasikan sebagai penyalahgunaan kewenangan. Namun, dapatkah secara serta pelanggaran pak lurah tersebut dikenai sanksi pidana sesuai ketentuan hukum UU No. 1 tahun 1974. Perbuatan Kelurahan yang semestinya melayani masyarakat tanpa adanya imbalan atau melebihi dari apa yang seharusnya menjadi dilematis untuk diproses, oleh karena ada elemen-elemen di luar ketentuan hukum yang mendorong terlembaganya pembayaran ilegal yang dipandang oleh mesyarakat sebagai cara untuk saling menolong dan meringankan beban hidup. Peristiwa ini tentu terjadi oleh karena Bekasi secara strategis tergolong wilayah transisional, dimana ledakan penduduk kota Jakarta berakibat negatif terhadap tatanan sosial, ekonomi masyarakat, termasuk pejabat kelurahan.

Dari segi aspek ekonomi, sebenarnya berapa gaji dan pendapatan sah seseorang

21 Lihat Mengejar Setoran, Namun Mengabaikan Penumpang. KOMPAS 25 Februari 2003.

${ }^{22}$ Lihat Kasus Pemerintah DK। Abaikan Menteri Lingkungan. Koran TEMPO, 24 Februari 2003. HIm.3 
Lurah bila dibandingkan dengan tamu-tamu yang datang, dengan kelas ekonomi tingkat kebutuhan atau kepentingan yang berbedabeda. Sehingga jumlah uang berapapun besarnya yang diminta pek Lurah menjadi sangat tidak terlalu berarti bila dibandingkan dengan pencapaian maksud dan tujuan para klien yang pola hidup mereka umumnya harus mempu menyesuaikan diri dengan kota metropolitan Jakarta. Tampak jelas faktor ekonomi dan kedisiplinan baik masyarakat maupun pejabat untuk mematuhi aturan hukum sangat rendah. Himpitan sosial kota Jakarta dimana legalitas menjadi instrumen kompetisi menjadi penyebab timbulnya dilema, termasuk pola ekonomi demonstration effect keluarga kelurahan tidak mungkin dapat menyumbangnya bilamana hanya menyandarkan pada gaji bulanan yang relatif kecil itu.

Kasus terakhir yang relevan bagi upaya mendiskripsikan penyalahgunaan wewenang yang dilakukan pejabat negara. Kementrian BUMN memberikan dana Rp 5 milyar kepada KONI Pusat untuk menutupi kekurangan pembiayaan persiapan dan pemberangkatan Kontingen Indonesia ke ASIAN GAMES XIV, Pusam Korea Selatan. September-Oktober 2002.

Kasus ini mengundang kontroversi di media dan mengundang para pakar untuk berkomentar. Namun, langkah lanjut berupa proses peradilan tidak juga timbul sampai dengan hari ini. Sebagai suatu kebijakan, pengeluaran uang sebanyak Rp 5 milyard tersebut jelas maksud dan tujuannya yaitu dalam upaya menyangkut martabat bangsa di mata internasional. Termasuk memberikan support, material dan immaterial bagi kader-kader olah raga Indonesia.

Persoalan yang timbul adalah benarkah pengeluaran uang tersebut dari APBN atau dana non - budgets yang terbebas dari berbagai motif. Ataukah memang Menteri BUMN memiliki niat dan maksud dengan dikeluarkannya tersebut. Masyarakat penggemar olah raga atau KONI dapat menjadi instrumen politik bagi upaya meraup keberhasilan Parpol Pemilu 2004.

Kondisi sebagaimana terlihat dalam kasus tersebut diatas menandakan bahwa kebijakan seseorang penguasa yang bertentangan dengan peraturan hukum, namun maksud dan tujuan dari tindakan diskresi itu dapat dipertanggungjawabkan tampaknya dapat mengalihkan pertanggungjawaban hukum. Sehingga bukan saja lembaga pengawas seperti DPR, Polisi, dan Jaksa tidak efektif, masyarakat itupun luput untuk memperkarakan hal tersebut.

Dengan demikian, penyalahgunaan wewenang dengan mengatasnamakan diskresi jelas telah menimbulkan persoalan dilematis bagi pelayanan publik, terutama karena tidak mudahnya penegakan hukum dapat ditrapkan secara efektif terhadap PNS dan pejabat sipil lainnya. Faktor-faktor seperti hukum, peraturan kebijakan, dan lemahnya penegakan termasuk penerapan sanksinya memang terlibat dalam menentukan bisa dan tidaknya seseorang oknum PNS di proses secara hukum. Lebih dari itu, faktor pilar hukum, seperti kondisi sosial ekonomi PNS dan budaya masyarakat tidak kalah pentingnya untuk dipertimbangkan dalam menggagas UU Pelayanan Publik yang efektif dalam mencegah dan menanggulangi diskresi yang cenderung menimbulkan penyalahgunaan kewenangan.

\section{Penutup}

Meskipun pada awalnya terdapat dua pandangan yang berbeda, gagasan tentang pembuatan draft Undang-Undang Pelayanan 
Publik tetap diharapkan dalam melengkapi berbagai kekuarangan yang ada dalam undang-undang organik dan undangundang non-organik di setiap departemen dan institusi pemerintahan. Namun, dalam kaitannya dengan asas-asas dan normanorma hukum yang secara teoritis telah berkembang di beberapa negara maju mengharuskan kita mempertimbangkan masukan relavan bagi pembentukan hukum pelayanan publik yang akuntabel. Perumusan obyek hukum publik terkait dengan pendidikan, kesehatan, kemiskinan memiliki sifat yang universal perlu mendapatkan penempatan prioritas.

Undang-Undang Pelayanan Publik dalam sistem pemerintahan yang baik (Good Governance) dan bersih (Clean Government) sangat penting mengingat kehadiran peran serta masyarakat (people participation) merupakan bagian dari sistem pengawasan terbuka. Sebab, kehadiran peraturan hukum pelayanan publik diharapkan dapat berfungsi memlihara keseimbangan, perlindungan dan kepastian dan kegunaan yang memeberikan kontribusi besar terhadap upaya negara dalam memberikan pelayanan yang memuaskan masyarakat, baik secara individual, kolektif, sosial dan keyakinan beragama. Tantangan NKRI kedepan salah satunya hanya mungkin dapat ditengarai bilamana sistem pelayanan oleh pemerintah dapat menerapkan asas dan norma ketelitian, keterbukaan (transparant), tidak diskriminasi ( nondiscriminatif), sikap netral atau mandiri (impertiality) sederajat (equality) dan keadilan (justice).

Terdapat tiga prinsip dasar yang semestinya dapat dijadikan kerangka utama dari suatu peraturan hukum UUPP. Secara filosofis, kehadiran UUPP sebenarnya tidak saja dalam rangka menciptakan masyarakat harmoni dan keseimbangan (keep community peacefully) terkait dengan pengamalan dasar negara yaitu dalam upaya menciptakan masyarakat yang adil dan makmur. Sedangkan parameter sosiologis akan tercapai makna dari suatu peraturan hukum bilamana harapan-harapan yang timbul akibat adanya hubungan hukum atau peristiwa-peristiwa yang ditemui dalam kehidupan sehari-hari, hubungan antara negara dengan swasta, atau masyarakat dengan perusahaan dapat menimbulkan kepuasan dan memperoleh perlindungan terhadap hal-hal pribadi dengan melindungi status jiwa, kebutuhan ekonomi, dan kesehatan, termasuk lingkungan. Dari perspektif juridis, undang-undang pelayanan publik selain harus memperjuangkan terpenuhinya hak-hak dan kewajibankewajjban secara benar seperti tertera dalam UUD 1945, terutama setelah diamandemen, dan juga dalam UU No 22/1999 dan UU 25/ 1999, sekaligus menjadi barometer kongkrit terhadap perlindungan hak-hak fundamental, HAM, termasuk di dalam jaminan tegaknya kesamaan peluang untuk memperoleh penyelesaian pertikaian, bajk melalui jalur pro justicia.

Luasnya ruang lingkup pelayanan publik telah menunjukan bahwa kehadiran undangundang (rule of law) dan peraturan kebijaksanaan (government discretion) akan tetap tidak akan pernah memadai dan efektif. Pandangan Weeramantri dan juga beberapa kasus di lapangan menujukan bahwa pejabat pemerintah cenderung bukan saja tidak konsisten dalam mematuhi sistem hukum. Lebih naif lagi mereka menyalah gunakan fungsi diskresi untuk suatu kepentingan tertentu bersifat pribadi. Penyalah gunaan kewenangan seperti korupsi, kolusi dan nepotisme tidak selalu dapat dipandang negatif sebegaimana ditemukan oleh Joso Abueve, melainkan menjadi berdampak yang sangat buruk 
seperti dialami dalam masa krisis Indonesia oleh karena sistem penegakan hukum dan pengawasannya yang dilakukan oleh institusi pemerintah dan aparatnya memang diakui tidak berdaya.

\section{Daftar Pustaka}

Cranston, Ross, 1985, Law in context Legal Foundations of the Welfare State, London: Weidenfeld and Nicolson.

Cranston, Ross,1987, Law, Government and Public Policy. Oxford: University Press.

Galligan. D.J. ,1990, Discretionary Powers : A Legal Study of Officials Discretion. Oxford: Clarendon Press.

Hadjon, Philiphus M. dan Tatiek Sri Djatmiarti. "Analisis Rancangan Norma Hukum Menyangkut Pelayanan Publik." Disampaikan dalam Seminar Konsepsi Pelayanan Publik dalam Rangka Penyusunan RUU Tentang Pelayanan Publik. Deputi Bidang Pelayanan Publik Kementrian, 16 April 2003, Jakarta.

Hunt, Alant,1981, The Politics of Law and Justice in Politics and Power: Law, Politics, and Justice. London: Rontledge \& Kegan Paul.

Laporan Akhir Naskah Akademik RUU Tentang Pelayanan Publik, Jakarta: Lembaga Penelitian UI.

Panel Diskusi, diselenggarakan oleh Departemen Aparatur Negara, tanggal 16 April 2003, Jakarta.
P.A.F. Lamintang, 1991, Delik-Delik Khusus Kejahatan Jabatan Tindak Pidana Korupsi; Bandung: CV, Pionir Jaya.

Romli Atmasasmita. "Kajian Terhadap Rancangan Undang-Undang Pelayanan Publik. Disampaikan dalam Seminar Konsepsi Pelayanan Publik dalam Rangka Penyusunan RUU Tentang Pelayanan Publik. Deputi Bidang Pelayanan Publik Kementrian, 16 April 2003, Jakarta.

Schur, Edwin M. 1974, Labeling, morals, and Public Policy, Lee Reinwater (edited), Social Problems and Public Policy: Devance and Liberty Chicago : Aldine Publishing Company,.

Saunders, John B.1977, Mozley \& Whiteley's Law Dictionary.(Ninth Edition). London: Butterworths.

Seminar Penyusunan Rancangan UU tentang Pelayanan Publik. Kementrian PAN, Deputi Bidang Pelayanan Publik, 2000.

Vago, Steven, 1981, Law and Society, New Jersey: Prantice Inc.

Weeramantry, 1975, C.G. The Law in Crisis: Bridges of Understanding. London: Capemoss,

Wertheim. W.F.1977, Segi-segi Sosiologis Korupsi di Asia Tenggara.Muchtar Lubis dan James Scott. Bunga Rampai Karangan-Karangan Etika Pegawai Negeri. Jakarta: Bhatara Karya Aksara. 